\title{
Quality characteristics of white (Baktae) and black (Seoritae) soybean curds coagulated by Omija extract
}

\author{
Chan-Ick Cheigh ${ }^{1}$, Hey-Kyung Moon ${ }^{2}$, Su-Won Lee ${ }^{2}$, Jong-Kuk Kim ${ }^{1 *}$ \\ ${ }^{1}$ Department of Food and Food Service Industry, Kyungpook National University, Sangju 37224, Korea \\ ${ }^{2}$ Center for Scientific Instruments, Kyungpook National University, Sangju 37224, Korea
}

\section{오미자 추출액을 응고제로 이용한 백태 및 서리태 두부의 품질특성}

\author{
최찬익 ${ }^{1} \cdot$ 문혜경 $^{2} \cdot$ 이수원 ${ }^{2} \cdot$ 김종국 $^{1 *}$ \\ ${ }^{1}$ 경북대학교 식품외식산업학과, ${ }^{2}$ 경북대학교 공동실험실습관
}

\begin{abstract}
In order to investigate the utilization of the Omija (Schizandra chinensis Baillon) extract as a natural coagulant for manufacturing soybean curd, the quality characteristics of white (Baktae) and black (Seoritae) soybean curds, coagulated by the Omija extract or $\mathrm{MgCl}_{2}$, were evaluated. Crude protein $(6.14 \pm 0.30$ and $6.25 \pm 0.18 \%$, respectively) and crude lipid (10.86 \pm 1.74 and $11.29 \pm 1.69 \%$, respectively) contents of white and black soybean curds coagulated using the Omija extract were higher than those coagulated using $\mathbf{M g C l}_{2}$. Black soybean curds coagulated using the Omija extract showed higher $\mathbf{L}$, a, and b values than those using $\mathbf{M g C l}_{2}$. The most abundant amino acid in white and black soybean curds coagulated using the Omija extract was arginine $(3.74$ and $3.71 \mathrm{mg} / 100 \mathrm{~g}$, dry basis, respectively). The amounts of $\mathrm{Ca}, \mathrm{K}, \mathrm{Mg}$, and $\mathrm{Na}$ were the highest in both soybean curds prepared with the Omija extract. The sensory evaluation (color, flavor, taste, texture, and overall preference) showed that white and black soybean curds coagulated using the Omija extract were more preferred than those produced using $\mathbf{M g C l}_{2}$. The results suggested that using the Omija extract as a natural coagulant agent could improve the quality and sensory characteristics of soybean curds.
\end{abstract}

Key words : Omija, soybean curd, natural coagulant, Baktae, Seoritae

\section{서 론}

두부는 전통적으로 우리나라와 중국, 일본 등에서 제조 되어 온 대표적인 콩 단백질 식품으로서 곡류 위주의 식생 활에서 부족하기 쉬운 리신(lysin)과 같은 필수아미노산 및 칼슘, 철분 등의 무기질이 다량으로 함유되어 있으며, 소화 흡수율이 높고, 값이 저렴하면서 간편하게 이용할 수 있는 양질의 단백질 식품이다(1-3). 두부는 이러한 영양학적 우 수성뿐만 아니라 daidzein 및 genistein 등의 isoflavones과

*Corresponding author. E-mail : kjk@knu.ac.kr

Phone : 82-54-530-1305, Fax : 82-54-530-1309

Received 21 January 2016; Revised 29 January 2016; Accepted 1 February 2016.

Copyright (c) The Korean Society of Food Preservation. All rights reserved.
사포닌, 레시틴 등을 함유하고 있어 성인병의 예방 및 치료 를 위한 기능성식품 소재로서도 관심과 연구의 대상이 되고 있다 $(4,5)$. 두부는 원료인 콩을 물에 불려 팽윤시킨 후 마쇄, 끓임, 여과의 과정을 통해 단백질 성분과 염류인 $\mathrm{Mg}^{2+}, \mathrm{Ca}^{2+}$ 성분을 침전 및 응고제로 응고시킨 후 압착의 과정을 거쳐 제조되고 있다(6). 일반적으로 두부는 수분 $85 \%$, 조단백질 $7.8 \%$, 조지방 $4.2 \%$ 그리고 $84 \mathrm{kcal} / 100 \mathrm{~g}$ 의 열량을 함유하고 있으나, 대두의 종류, 두유의 추출조건 및 농도, 응고제의 종류 및 응고조건 등에 따라 두부의 품질 및 성분이 영향 받는 것으로 알려져 있다 $(7,8)$

두부의 원료로 사용되는 콩은 항산화 능력이 뛰어난 것 으로 알려져 있는데, 다른 종류의 콩들보다 검정콩이 더 높은 항산화력을 갖는 것으로 보고되었다(9). 검정콩은 콩 과(Leguminosae)에 속하며 특정한 한 종류의 콩을 가리키 는 것이 아니라 검은빛을 띄는 콩을 총칭하는 말이며 흑태, 
서리태, 서목태가 이에 속한다(10). 그 중 서리태는 껍질이 검고 속은 파란빛을 띄는 콩으로 검은콩 중 크기가 가장 크며, 수분 $8.9 \%$, 당 $25.3 \%$, 조단백질 $42.3 \%$, 조지방 $19.0 \%$, 회분 $4.5 \%$ 로 구성되어 있을 뿐만 아니라, 종피에 다량 함유 된 안토시아닌 색소가 항산화 활성을 포함한 여러 가지 기능성을 나타내는 것으로 보고되고 있다 $(9,11,12)$.

두부 제조의 핵심 공정인 응고는 2 가 금속염 또는 산을 대두 단백질에 첨가함으로써 망상구조를 형성하여 내부에 수분을 포집하는 일종의 겔화(gelatinization)이며, 이 과정 에서 주로 사용되는 응고제로는 염화마그네슘 $\left(\mathrm{MgCl}_{2}\right)$, 염 화칼슘 $\left(\mathrm{CaCl}_{2}\right)$, 황산칼슘 $\left(\mathrm{CaSO}_{4}\right)$ 등의 화학응고제로 최근 웰빙 문화와 건강에 관심이 높은 소비자들에게 우려의 대상 이 되고 있는 실정이다 $(13,14)$. 따라서 화학응고제를 대체 할 수 있는 천연간수나 해양심층수(15)의 이용과 더불어 천연응고제로서 매실즙(16), 젖산 칼슘(17), 시금치즙(18), 석류 농축액(19) 등을 이용한 연구들이 보고되고 있다.

오미자(Omija)는 단맛, 쓴맛, 매운맛, 신맛, 짠맛의 다섯 가지 맛을 내며 안토시아닌에 의해 심홍색을 나타내는 낙엽 덩굴성 다년생 목련과 식물인 오미자나무(Schizandra chinensis Baillon)의 열매이다(20). 예로부터 동양의학에서 는 오미자를 진정, 진해, 혈압 조절 및 알코올 분해제로 사용하여 왔으며 최근에는 오미자에 의한 면역 조절, 혈당 강하, 항암 및 항산화 효능 등 다양한 생리활성이 보고되고 있다(21-23). 오미자의 주성분은 리그난(lignan) 화합물이 며 palmitic acid와 stearic acid 등의 지방산과 citric acid, malic acid 및 succinic acid 등의 유기산을 함유하고 있는데 (24), 특히 이들 유기산은 두부 제조 시 대두 단백질과 반응 하여 천연응고제로서의 활용이 가능하다.

따라서 본 연구는 다양한 생리활성을 가진 오미자 추출 액을 천연응고제로 이용하여 제조된 백태 및 서리태 두부의 이화학적 품질 특성 및 관능적 특성을 분석함으로써 서리태 및 오미자를 활용한 기능성 두부의 개발 및 기존의 화학응 고제에 대한 오미자 추출액의 대체 가능성을 비교 평가하고 자 하였다.

\section{재료 및 방법}

\section{실험재료}

본 실험에 사용된 백태 및 서리태는 경상북도 상주농협 에서 2013년 10월에 구입한 것을 사용하였으며, 오미자는 문경 산동농협에서 2013년 10월에 구입하여 사용하였다. 실험에 사용된 오미자의 일반성분 분석결과는 Table 1 과 같았으며, 시료 중량에 대하여 10 배의 증류수를 첨가한 후 $80^{\circ} \mathrm{C}$ 에서 3 시간 동안 환류냉각하면서 반복 추출하였다. 추 출액은 $4,000 \mathrm{rpm}$ 에서 10 분 동안 원심분리 후 Whatman No. 5(Whatman plc, Kent, UK)로 여과하여 실험에 사용하였
으며, 오미자 추출액의 $\mathrm{pH}$ 및 가용성 고형분 함량은 각각 2.85 와 $11.50 \pm 0.49{ }^{\circ} \mathrm{Brix}$ 였다.

Table 1. Approximate composition of Omija

(unit: \%)

\begin{tabular}{ccccccc}
\hline & Moisture & $\begin{array}{c}\text { Crude } \\
\text { protein }\end{array}$ & $\begin{array}{c}\text { Crude } \\
\text { lipid }\end{array}$ & $\begin{array}{c}\text { Crude } \\
\text { fiber }\end{array}$ & Ash & $\begin{array}{c}\text { N-free } \\
\text { extract }\end{array}$ \\
\hline Omija & $81.26 \pm 1.13^{1)}$ & $3.72 \pm 0.21$ & $5.13 \pm 0.13$ & $0.79 \pm 0.08$ & $0.86 \pm 0.06$ & $8.24 \pm 0.31$
\end{tabular}

${ }^{1)}$ Values are expressed as mean $\pm \mathrm{SD}(\mathrm{n}=3)$.

두부의 제조

대두를 수세하여 12 시간 실온에서 침지한 후 대두 무게 10 배의 증류수를 조금씩 가하면서 습식 분쇄기로 마쇄하여 두미를 제조하였으며, 제조된 두미를 $100^{\circ} \mathrm{C}$ 에서 10 분간 가 열한 후 여과포에 넣어 압착하여 유백색의 두유를 얻었다. 두유를 $80^{\circ} \mathrm{C}$ 로 조절하여 대조군 $\left(2.0 \% \mathrm{MgCl}_{2}\right)$ 과 오미자 추 출액 첨가군 $(0.5,1.0,3.0,5.0 \%)$ 으로 나누어 20 분 동안 정치 하여 응고시켰으며, 오미자 추출액 첨가군 가운데 $5.0 \%$ 농도로 첨가했을 때 두부의 응고가 가장 잘 이루어져 해당 농도로 두부를 제조하였다. 응고물을 여과포가 깔린 두부 성형틀 $(10 \times 10 \times 8 \mathrm{~cm})$ 에 넣고 $20 \mathrm{~g} / \mathrm{cm}^{2}$ 의 압력으로 30 분 동 안 압착 성형하여 두부를 제조하였다.

\section{일반성분 분석}

오미자 및 두부의 일반성분은 $\mathrm{AOAC}$ 법에 따라 분석하였 다(25). 즉, 수분 함량은 $105^{\circ} \mathrm{C}$ 상압가열건조법으로 측정하 였고, 조단백 함량은 micro-Kjeldahl 질소정량법을 이용하 여 측정하였다. 조지방 함량은 Soxhlet 추출법을 그리고 조회분 함량은 직접회화법으로 측정하여 백분율로 나타내 었다.

\section{색도 측정}

색도는 Chromameter(CR-300, Minolta Co., Tokyo, Japan) 를 사용하여 3 회 반복 측정하였으며, Hunter color value인 명도(lightness, L), 적색도(redness, a), 황색도(yellowness, b)를 측정하여 total color difference $(\Delta \mathrm{E})$ 로 나타내었다. 이때 사용된 표준백색판의 $\mathrm{L}, \mathrm{a}$ 및 $\mathrm{b}$ 값은 각각 $93.89,1.85,1.39$ 이었다.

\section{$\mathrm{pH}$, 당도 및 염도 측정}

두부의 당도, 염도 및 $\mathrm{pH}$ 의 측정을 위해 시료 $5 \mathrm{~g}$ 을 취하 여 증류수 $50 \mathrm{~mL}$ 를 가해 균질화 시킨 후 각각 디지털 당도 계(PR 201, Atago Co., Tokyo, Japan), 디지털 염도계 (ES-421, Atago Co., Tokyo, Japan), 그리고 $\mathrm{pH}$ meter (Delta320, Mettler-Toledo Inc., Shanghai, China)를 사용하여 3회 반복 측정하여 평균값으로 나타내었다. 
아미노산 분석

아미노산의 조성 및 함량 분석을 위해 동결 건조한 두부 시료 $10 \mathrm{~g}$ 에 $75 \%$ ethanol $100 \mathrm{~mL}$ 을 가하여 $80^{\circ} \mathrm{C}$ 에서 2 시간 동안 반복 추출한 후 이를 여과한 여액을 $45^{\circ} \mathrm{C}$ 에서 감압 농축하여 $0.2 \mathrm{M}$ sodium citrate buffer( $\mathrm{pH}$ 2.2)용액으로 정용 하고, Sep-Pak $\mathrm{C}_{18}$ (Waters Co., Milford, MA, USA)으로 처리 한 후 $0.45 \mu \mathrm{m}$ membrane filler(Whatman, Dassel, Germany) 로 재여과하였다. 준비된 시료액은 automatic amino acid analyzer(Biochrom 30, Peek U-1631 column, Cambridge, UK, bed length $200 \mathrm{~mm}$, diameter $4.6 \mathrm{~mm}$, flow rate 20 $\mathrm{mL} / \mathrm{hr}$ )를 사용하여 분석하였다.

\section{무기질 분석}

시료 $5 \mathrm{~g}$ 를 $550^{\circ} \mathrm{C}$ 에서 건식회화 및 방냉 한 후 증류수로 적시고 $\mathrm{HCl}: \mathrm{H}_{2} \mathrm{O}(1: 1)$ 용액 $10 \mathrm{~mL}$ 를 가하여 용해시켰다. 이 를 $80^{\circ} \mathrm{C}$ 에서 30 분 동안 증발 건고시키고 $\mathrm{HCl}: \mathrm{H}_{2} \mathrm{O}(1: 3)$ 용액 $10 \mathrm{~mL}$ 를 가하여 Whatman No. 41(ashless)로 여과한 후 증류 수 $100 \mathrm{~mL}$ 로 정용한 다음 inductively coupled plasma spectrometer(ICP, Thermo Jarrell Ash, Franklin, MA, USA) 로 분석하였다. 분석 항목은 $\mathrm{Ca}, \mathrm{Cu}, \mathrm{K}, \mathrm{Mg}, \mathrm{Mn}, \mathrm{Mo}, \mathrm{Na}$, $\mathrm{Zn}$ 이었으며, 각각 3 회 반복 측정하였다.

\section{관능검사}

제조된 두부의 종류에 따른 색, 향, 맛, 조직감 및 전체적 인 기호도에 대하여 경북대학교 식품외식산업학과 대학 및 대학원생 20 명을 대상으로 관능평가를 실시하였다. 동 일한 크기로 절단된 두부를 흰색 접시에 담아 검사를 수행 하였고, 각 시료에 대하여 5점 척도법(5, 대단히 좋다; 4 , 약간 좋다, 3 , 보통이다; 2 , 약간 나쁘다, 1 , 대단히 나쁘다)으 로 3 회 반복하여 평가하였다.

\section{통계분석}

본 연구의 통계분석은 SPSS 프로그램(22.0, SPSS Inc., Chicago, IL, USA)을 이용하여 수행하였다. 실험 결과는 평균표준편차로 나타내었고, 천연응고제인 오미자 추출 액과 대조군으로 사용된 $\mathrm{MgCl}_{2}$ 간의 유의성은 Student's t-test를 실시하여 검정하였다.

\section{결과 및 고찰}

일반성분

천연응고제인 오미자 추출액 및 대조군으로써 $\mathrm{MgCl}_{2}$ 를 이용하여 제조한 백태 및 서리태 두부의 일반성분에 대한 분석 결과는 Table 2에 나타내었다. 수분 함량은 백태 및 서리태 두부 모두에서 오미자 추출액 첨가구(77.85 \pm 1.07 및 $78.04 \pm 1.60 \%)$ 가 $\mathrm{MgCl}_{2}$ 첨가구(82.65 \pm 1.39 및 $81.97 \pm$ $2.22 \%$ )보다 낮은 값을 나타냈는데 이는 오미자 추출액으로 응고 시 $\mathrm{MgCl}_{2}$ 보다 약간 큰 입자의 형성으로 인해 성형 시 상대적으로 보다 많은 수분이 유출된 결과로 사료된다. 단백질 및 지방의 함량은 오미자 추출액 첨가구에서 백태 $(6.14 \pm 0.30$ 및 $10.86 \pm 1.74 \%)$ 와 서리태 두부(6.25 \pm 0.18 및 $11.29 \pm 1.69 \%)$ 모두 $\mathrm{MgCl}_{2}$ 첨가구보다 높게 나타났다. 회분 함량은 $\mathrm{MgCl}_{2}$ 첨가구가 백태 및 서리태 두부 모두에서 오미 자 추출액 첨가구 $(0.69 \pm 0.15$ 및 $0.49 \pm 0.14 \%)$ 보다 높게 나타 났는데 이는 화학응고제인 $\mathrm{MgCl}_{2}$ 의 사용 때문으로 사료된 다. 오미자 추출액 및 $\mathrm{MgCl}_{2}$ 첨가 백태 및 서리태 두부의 일반성분은 전반적으로 국내산 대두로 제조된 두부의 일반 성분 함량과 큰 차이를 보이지 않았으나(26), 앞서 언급한 바와 같이 오미자 추출액 첨가구에서 다소 수분 함량이 감소되는 현상을 확인하였으며, 이는 유기산의 농도 증가 에 따른 급속한 단백질 응고와 이에 따른 보수력 저하 현상 때문으로 사료된다 $(16,19,27)$.

\section{두부의 색도}

오미자 추출액 및 $\mathrm{MgCl}_{2}$ 를 이용하여 제조한 백태와 서리 태 두부의 색도를 비교 측정한 결과를 Table 3에 나타내었 다. $\mathrm{L}$ 값은 백태 두부의 경우 $\mathrm{MgCl}_{2}$ 첨가구가 오미자 추출액 첨가구 $(84.87 \pm 0.55)$ 보다 높게 나타났고, 서리태 두부에서 는 오미자 추출액 첨가구가 $66.32 \pm 1.34$ 로 $\mathrm{MgCl}_{2}$ 첨가구보 다 높게 나타났다. $\mathrm{a}$ 값은 오미자 추출액 첨가구가 백태 $(0.97 \pm 0.13)$ 및 서리태 두부(3.29 \pm 0.07$)$ 모두에서 대조군보 다 높게 나타났으며, $\mathrm{b}$ 값은 오미자 추출액 첨가 백태 두부 (13.45 \pm 0.59 )의 경우 $\mathrm{MgCl}_{2}$ 보다 낮게 측정되었으며, 오미 자 추출액 첨가 서리태 두부(11.59 1.69$)$ 는 대조군보다 높 은 값을 나타내었다. 이와 같은 결과는 두부 제조에 사용된 콩의 색깔 및 오미자에서 유래된 색소에 의해 $\mathrm{L}, \mathrm{a}, \mathrm{b}$ 값이

Table 2. Approximate composition of soybean curds coagulated with the Omija extract

\begin{tabular}{ccccccc}
\multicolumn{1}{c}{} & \multicolumn{1}{c}{} & & & (unit: \%) \\
\hline \multirow{3}{*}{ White bean } & Variety & Moisture & Crude protein & Crude lipid & Ash & N-free extract \\
& $\mathrm{MgCl}_{2}$ & $82.65 \pm 1.39^{1)}$ & $4.42 \pm 0.31$ & $9.47 \pm 0.20$ & $0.76 \pm 0.26$ & $2.70 \pm 0.06$ \\
& Omija extract & $77.85 \pm 1.07$ & $6.14 \pm 0.30$ & $10.86 \pm 1.74$ & $0.69 \pm 0.15$ & $4.46 \pm 0.23$ \\
\hline \multirow{2}{*}{ Black bean } & $\mathrm{MgCl}_{2}$ & $81.97 \pm 2.22$ & $4.33 \pm 0.02$ & $8.84 \pm 0.19$ & $1.00 \pm 0.08$ & $3.86 \pm 0.20$ \\
& Omija extract & $78.04 \pm 1.60$ & $6.25 \pm 0.18$ & $11.29 \pm 1.69$ & $0.49 \pm 0.14$ & $3.93 \pm 0.10$ \\
\hline
\end{tabular}

\footnotetext{
${ }^{1)}$ Values are expressed as mean \pm SD $(n=3)$.
} 
크게 영향을 받아 각각 다르게 나타나는 것으로 사료된다. 두부 제조 시, 허브를 첨가하거나 연잎을 첨가하여 두부를 제조하는 경우에도 이와 유사한 현상이 관찰됨이 보고된 바 있다 $(28,29)$.

Table 3. Color value of soybean curds coagulated with the Omija extract

\begin{tabular}{ccccc}
\hline \multirow{2}{*}{ Variety } & \multicolumn{3}{c}{ Hunter's color values } \\
\cline { 3 - 5 } & & $\mathrm{L}$ & $\mathrm{a}$ & $\mathrm{b}$ \\
\hline \multirow{2}{*}{ White bean } & $\mathrm{MgCl}_{2}$ & $88.20 \pm 0.93^{1)}$ & $-0.47 \pm 0.11$ & $14.19 \pm 0.35$ \\
& Omija extract & $84.87 \pm 0.55$ & $0.97 \pm 0.13$ & $13.45 \pm 0.59$ \\
\hline \multirow{3}{*}{ Black bean } & $\mathrm{MgCl}_{2}$ & $63.42 \pm 0.99$ & $1.86 \pm 0.15$ & $8.83 \pm 0.23$ \\
& Omija extract & $66.32 \pm 1.34$ & $3.29 \pm 0.07$ & $11.59 \pm 1.69$ \\
\hline
\end{tabular}

${ }^{1)}$ Values are expressed as mean \pm SD $(n=3)$.

\section{$\mathrm{pH}$, 당도 및 염도}

오미자 추출액을 첨가한 백태와 서리태 두부의 $\mathrm{pH}$, 당도 및 염도를 $\mathrm{MgCl}_{2}$ 첨가 두부와 비교 분석하였다(Table 4). $\mathrm{pH}$ 는 백태 및 서리태 두부 모두에서 오미자 추출액 첨가구 (5.39 \pm 0.17 및 $5.43 \pm 0.28$ )가 $\mathrm{MgCl}_{2}$ 첨가구(4.61 \pm 0.33 및 $4.85 \pm 0.22)$ 보다 높은 값을 나타냈으나, 당도는 이와 대조적 으로 백태 및 서리태 두부 모두에서 오미자 추출액 첨가구 $\left(1.53 \pm 0.30\right.$ 및 $\left.1.92 \pm 0.15{ }^{\circ} \mathrm{Brix}\right)$ 가 $\mathrm{MgCl}_{2}$ 첨가구보다 낮게 나타났다. 염도 역시 당도와 유사한 경향을 보였는데, 오미 자 추출액 첨가 백태 및 서리태 두부의 염도는 각각 $0.08 \pm 0.01 \%$ 및 $0.12 \pm 0.03 \%$ 로 $\mathrm{MgCl}_{2}$ 첨가구보다 낮게 나타 났다.

Table 4. $\mathrm{pH}$, soluble solid, and salt contents of soybean curds coagulated with the Omija extract

\begin{tabular}{ccccc}
\hline \multicolumn{2}{c}{ Variety } & $\mathrm{pH}$ & $\begin{array}{c}\text { Soluble solids } \\
\left({ }^{\circ} \text { Brix }\right)\end{array}$ & Salt (\%) \\
\hline \multirow{2}{*}{ White bean } & $\mathrm{MgCl}_{2}$ & $4.61 \pm 0.33^{1)}$ & $3.02 \pm 0.11$ & $0.71 \pm 0.06$ \\
& Omija extract & $5.39 \pm 0.17$ & $1.53 \pm 0.30$ & $0.08 \pm 0.01$ \\
\hline \multirow{2}{*}{ Black bean } & $\mathrm{MgCl}_{2}$ & $4.85 \pm 0.22$ & $3.09 \pm 0.08$ & $0.91 \pm 0.20$ \\
& Omija extract & $5.43 \pm 0.28$ & $1.92 \pm 0.15$ & $0.12 \pm 0.03$ \\
\hline
\end{tabular}

${ }^{1)}$ Values are expressed as mean \pm SD $(n=3)$.

아미노산의 조성 및 함량

오미자 추출액 및 $\mathrm{MgCl}_{2}$ 를 이용하여 제조한 백태 및 서리 태 두부의 아미노산 조성 및 함량을 비교 측정하여 Table 5 에 나타내었다. 백태 두부의 경우, aspartic acid, serine isoleucine은 오미자 추출액 첨가구에서만 관찰되었고, 대 조구에서 측정되었던 threonine, leucine, tyrosine, phenylalanine 은 오미자 추출액 첨가구에서 측정되지 않았다. Arginine은 오미자 추출액 첨가구 $\left(3.74 \mathrm{mg} / 100 \mathrm{~g}\right.$, dry basis) 및 $\mathrm{MgCl}_{2}$
첨가구 $(9.01 \mathrm{mg} / 100 \mathrm{~g})$ 모두에서 가장 높은 아미노산 함량 을 보였으며, proline과 methionine은 두 첨가구 모두 나타나 지 않았다. 서리태 두부의 경우에도 마찬가지로 오미자 추 출액 첨가구 $(3.71 \mathrm{mg} / 100 \mathrm{~g})$ 및 $\mathrm{MgCl}_{2}$ 첨가구 $(7.99 \mathrm{mg} / 100$ g) 모두에서 arginine이 가장 높은 수치를 보였으나, proline, methionine, isoleucine, leucine은 두 첨가구 모두에서 관찰 되지 않았다. $\mathrm{MgCl}_{2}$ 및 오미자 추출액을 첨가한 백태(33.21 및 $12.66 \mathrm{mg} / 100 \mathrm{~g})$ 와 서리태 $(26.79$ 및 $14.06 \mathrm{mg} / 100 \mathrm{~g})$ 두부 의 전체 아미노산 함량은 전반적으로 $\mathrm{MgCl}_{2}$ 첨가구가 오미 자 추출액 첨가구보다 높았으며, 이는 두 첨가제의 응고 방식에 따른 차이 때문으로 사료된다. $\operatorname{Kim}(30)$ 은 원료 대두 의 특성에 따라 제조된 두부의 아미노산 조성이 다르며, 백태 및 흑태의 가공에 의해 만들어진 두부가 원료인 콩과 비교하여 영양적인 측면에서 다소 우수함을 보고한 바 있다.

Table 5. Amino acid contents of soybean curds coagulated with the Omija extract

\begin{tabular}{lcccc} 
& \multicolumn{4}{c}{ (unit: $\mathrm{mg} / 100 \mathrm{~g}$, dry basis) } \\
\hline \multirow{2}{*}{ Amino acid } & \multicolumn{2}{c}{ White bean } & \multicolumn{2}{c}{ Black bean } \\
\cline { 2 - 5 } Aspartic acid & $\mathrm{MgCl}_{2}$ & Omija extract & $\mathrm{MgCl}_{2}$ & Omija extract \\
Threonine & - & 0.23 & - & 0.28 \\
Serine & 2.16 & - & 2.09 & 0.31 \\
Glutamic acid & - & 0.30 & 0.31 & 0.35 \\
Proline & 4.25 & 1.00 & 2.43 & 1.24 \\
Glycine & - & - & - & - \\
Alanine & 0.77 & 0.23 & 0.92 & 0.49 \\
Cystine & 1.75 & 0.49 & 1.43 & 0.66 \\
Valine & 3.37 & 1.57 & 2.25 & 1.48 \\
Methionine & 0.99 & 0.47 & 0.78 & - \\
Isoleucine & - & - & - & - \\
Leucine & - & 0.42 & - & - \\
Tyrosine & 0.81 & - & - & - \\
Phenylalanine & 1.76 & - & 1.15 & 0.57 \\
Histidine & 1.79 & - & 0.55 & 0.72 \\
Lysine & 1.11 & 0.38 & 1.13 & 0.36 \\
Arginine & 1.71 & 0.41 & 1.88 & 0.42 \\
Ammonium chloride & 3.73 & 3.74 & 7.99 & 3.71 \\
\hline \multicolumn{1}{c}{ Total amino acids } & 33.21 & 12.66 & 26.79 & 14.06 \\
\hline & & & &
\end{tabular}

\section{무기질의 조성 및 함량}

오미자 추출액 및 $\mathrm{MgCl}_{2}$ 를 이용하여 제조한 백태 및 서리 태 두부의 무기질 조성 및 함량을 비교 측정하여 Table 6에 나타내었다. 백태 두부의 경우, $\mathrm{MgCl}_{2}$ 첨가 구에서 $\mathrm{Ca}(15.20 \mathrm{mg} / 100 \mathrm{~g}$, dry basis $), \mathrm{K}(28.89 \mathrm{mg} / 100 \mathrm{~g})$, 
$\operatorname{Mg}(144.04 \mathrm{mg} / 100 \mathrm{~g})$ 이 오미자 추출액 첨가구보다 높은 값을 나타냈으며, 오미자 추출액 첨가구에서는 $\mathrm{K}(21.14$ $\mathrm{mg} / 100 \mathrm{~g}), \mathrm{Mg}(7.35 \mathrm{mg} / 100 \mathrm{~g}), \mathrm{Na}(4.15 \mathrm{mg} / 100 \mathrm{~g}), \mathrm{Ca}(4.08$ $\mathrm{mg} / 100 \mathrm{~g}$ )이 높은 측정값을 나타냈다. $\mathrm{Cu}, \mathrm{Mn}, \mathrm{Mo}, \mathrm{Zn}$ 은 두 첨가구 모두에서 비슷한 값을 나타내었다. 서리태로 제 조한 두부에서도 마찬가지로 $\mathrm{MgCl}_{2}$ 첨가구에서 $\mathrm{Ca}(16.00$ $\mathrm{mg} / 100 \mathrm{~g}), \mathrm{K}(35.09 \mathrm{mg} / 100 \mathrm{~g}), \mathrm{Mg}(163.15 \mathrm{mg} / 100 \mathrm{~g})$ 이 오미 자 추출액 첨가구보다 높은 값을 나타내었고, 오미자 추출 액 첨가구에서는 $\mathrm{K}(25.81 \mathrm{mg} / 100 \mathrm{~g}), \mathrm{Mg}(6.86 \mathrm{mg} / 100 \mathrm{~g})$, $\mathrm{Na}(4.75 \mathrm{mg} / 100 \mathrm{~g}), \mathrm{Ca}(3.27 \mathrm{mg} / 100 \mathrm{~g})$ 이 높은 측정값을 나타내었다. $\mathrm{Cu}$ 와 $\mathrm{Mo}$ 는 두 첨가구 모두에서 비슷한 값을 나타내었다. 위의 결과에서 $\mathrm{MgCl}_{2}$ 첨가 백태 $(144.04 \mathrm{mg} / 100$ $\mathrm{g})$ 및 서리태 $(163.15 \mathrm{mg} / 100 \mathrm{~g})$ 두부의 $\mathrm{Mg}$ 함량이 매우 높은 측정값을 나타내었는데 이것은 응고제로 사용한 $\mathrm{MgCl}_{2}$ 의 영향으로 사료된다(31). 또한 백태 및 서리태 두부 모두에서 높은 농도로 측정된 $\mathrm{K}, \mathrm{Mg}, \mathrm{Na}, \mathrm{Ca}$ 등 양이온들은 두부 제조 시 두유 중에 균일하게 확산되어 단백질의 응고에 관여함으로써 두부의 겔 형성 능력을 증가시키는 것으로 판 단된다(32).

Table 6. Mineral contents of soybean curds coagulated with the Omija extract

\begin{tabular}{ccccc} 
& \multicolumn{2}{c}{ (unit: $\mathrm{mg} / 100 \mathrm{~g}$, dry basis) } \\
\hline \multirow{2}{*}{ Mineral } & \multicolumn{2}{c}{ White bean } & \multicolumn{2}{c}{ Black bean } \\
\cline { 2 - 5 } & $\mathrm{MgCl}_{2}$ & Omija extract & $\mathrm{MgCl}_{2}$ & Omija extract \\
\hline $\mathrm{Ca}$ & 15.20 & 4.08 & 16.00 & 3.27 \\
$\mathrm{Cu}$ & 0.01 & 0.11 & 0.14 & 0.11 \\
$\mathrm{~K}$ & 28.89 & 21.14 & 35.09 & 25.81 \\
$\mathrm{Mg}$ & 144.04 & 7.35 & 163.15 & 6.86 \\
$\mathrm{Mn}$ & 0.12 & 0.02 & 0.21 & 0.01 \\
$\mathrm{Mo}$ & 0.00 & 0.00 & 0.05 & 0.02 \\
$\mathrm{Na}$ & 2.27 & 4.15 & 2.77 & 4.75 \\
$\mathrm{Zn}$ & 0.70 & 0.54 & 0.92 & 0.45 \\
\hline
\end{tabular}

관능평가

오미자 추출액 및 $\mathrm{MgCl}_{2}$ 를 이용하여 제조한 백태 및 서리 태 두부의 관능특성을 5점 채점법을 이용하여 평가한 결과 를 Table 7에 나타내었다. 백태로 제조한 두부에서 오미자
추출액을 첨가한 구가 색, 두부 고유의 향기, 두부 고유의 맛, 조직감에서 모두 $\mathrm{MgCl}_{2}$ 첨가구보다 높은 점수를 얻었으 며, 전체적인 기호도 역시 $4.36 \pm 0.47$ 로 $\mathrm{MgCl}_{2}$ 첨가구보다 높은 점수를 나타내었다. 서리태로 제조한 두부에서 역시 색, 두부 고유의 향기, 두부 고유의 맛, 조직감에서 오미자 추출액 첨가구가 $\mathrm{MgCl}_{2}$ 첨가구보다 높은 점수를 나타내었 고 전체적인 기호도에서 역시 오미자 추출액 첨가구가 $4.21 \pm 0.32$ 로 더 높은 점수를 나타내었다. 이와 같은 결과는 두부의 제조에 있어 화학응고제보다 오미자 추출액을 이용 한 천연응고제의 사용이 두부의 기호도 향상에 영향을 미치 는 것으로 판단되며, $\mathrm{Kim}$ 과 $\mathrm{Choi}(33)$ 는 오미자 추출물 $1 \%$ 를 첨가하여 두부를 제조한 경우 두부의 전반적인 관능평가 결과가 상승했음을 보고한 바 있다.

\section{요 약}

다양한 생리활성을 가진 오미자 추출액을 천연응고제로 이용한 백태 및 서리태 두부의 이화학적 품질 특성 및 관능 적 특성을 분석하고 오미자를 활용한 다양한 기능성 두부의 개발 및 기존의 화학응고제에 대한 오미자 추출액의 대체 가능성을 비교 평가하였다. 오미자 추출액 첨가 백태 및 서리태 두부의 수분 및 회분 함량은 $\mathrm{MgCl}_{2}$ 첨가구보다 낮았 으나, 단백질 및 지방의 함량은 오미자 추출액 첨가구에서 높게 관찰되었으며, 색도는 전반적으로 두부 제조에 사용 된 콩의 색깔에 따라 영향을 받은 것으로 확인되었다. $\mathrm{pH}$ 는 오미자 추출액 첨가구에서 $\mathrm{MgCl}_{2}$ 첨가구보다 높게 나타났 으며, 당도 및 염도는 오미자 추출액 첨가구가 대조군보다 낮은 값을 보였다. 아미노산 함량은 모든 백태 및 서리태 시료에서 arginine이 가장 높게 관찰되었으나, 전반적으로 오미자 추출액 첨가구(3.74 및 $3.71 \mathrm{mg} / 100 \mathrm{~g}$ )보다 $\mathrm{MgCl}_{2}$ 첨가구 $(9.01$ 및 $7.99 \mathrm{mg} / 100 \mathrm{~g})$ 에서 더 높은 값을 보였다. 무기질 함량은 백태 및 서리태 두부 모두 $\mathrm{Ca}, \mathrm{K}, \mathrm{Mg}, \mathrm{Na}$ 의 함량이 두 첨가구 모두에서 높은 값을 보였으며, 대체적으 로 $\mathrm{MgCl}_{2}$ 첨가구가 오미자 추출액 첨가구보다 높은 값을 나타내었다. 이들 두부에 대한 관능평가 결과, 모든 시료에 서 오미자 추출액 첨가구가 색, 두부 고유의 향기, 두부 고유의 맛, 조직감에서 모두 $\mathrm{MgCl}_{2}$ 첨가구보다 높은 점수를

Table 7. Sensory characteristics of soybean curds coagulated with the Omija extract

\begin{tabular}{|c|c|c|c|c|c|c|}
\hline \multicolumn{2}{|c|}{ Variety } & Color & Flavor & Taste & Texture & Overall preference \\
\hline \multirow{2}{*}{ White bean } & $\mathrm{MgCl}_{2}$ & $3.57 \pm 0.13^{1)}$ & $3.12 \pm 0.31$ & $3.00 \pm 0.62$ & $3.71 \pm 0.11$ & $3.21 \pm 0.53$ \\
\hline & Omija extract & $4.00 \pm 0.32^{*}$ & $4.05 \pm 0.30^{* *}$ & $4.85 \pm 0.49^{* *}$ & $4.28 \pm 0.37^{*}$ & $4.36 \pm 0.47^{* *}$ \\
\hline \multirow{2}{*}{ Black bean } & $\mathrm{MgCl}_{2}$ & $2.57 \pm 0.39$ & $3.33 \pm 0.15$ & $3.00 \pm 0.36$ & $3.42 \pm 0.53$ & $3.57 \pm 0.18$ \\
\hline & Omija extract & $3.11 \pm 0.21^{*}$ & $4.25 \pm 0.22^{* * *}$ & $3.98 \pm 0.45^{* *}$ & $4.42 \pm 0.60^{*}$ & $4.21 \pm 0.32^{* *}$ \\
\hline
\end{tabular}

${ }_{* * * * * * *}^{1)}$ alues are expressed as mean $\pm \mathrm{SD}$.

$*{ }^{*},{ }^{* k *}$ mean significant differences $\left(\mathrm{p}<0.1, \mathrm{p}<0.05\right.$, and $\mathrm{p}<0.01$, respectively) between $\mathrm{MgCl}_{2}$ and Omija extract by Student's $\mathrm{t}$-test. 
얻었으며 전체적인 기호도 역시 $\mathrm{MgCl}_{2}$ 첨가구보다 높은 점수를 나타내었다. 본 연구의 결과는 건강 기능성을 가진 오미자 추출액만을 첨가하여 두부를 응고시키고 제조하는 것이 가능함을 보여주고 있으며, 이는 건강에 대한 부정적 인 측면을 갖는 화학응고제의 대체재로써 오미자 추출액 천연응고제의 상업적 활용 가능성을 제시하고 있다.

\section{감사의 글}

이 논문은 2012학년도 경북대학교 학술연구비에 의하여 연구되었음.

\section{References}

1. Kim MJ, Kim HT, Choi YB, Hwang HS, Kim TY (1993) Effects of cow's milk addition on the quality of soybean curd. J Korean Soc Food Nutr, 22, 437-442

2. Kim H, Kim KA, Cha EJ, Han NS (2005) Property analysis of soybean curd produced by automatic and consecutive processes. Food Eng Prog, 9, 303-308

3. Park KN, Park LY, Kim DG, Park GS, Lee SH (2007) Effect of turmeric (Curcuma aromatica Salab.) on shelf life of tofu. Korean J Food Preserv, 14, 136-141

4. Liu K (2012) Soybeans : chemistry, technology and utilization. Springer-Verlag, Berlin, Germany, p 505-514

5. Dwyer JT, Goldin BR, Saul N, Gualtieri L, Barakat S, Aldercreuta H (1994) Tofu and soy drinks contain phytoestrogens. J Am Diet Assoc, 94, 739-743

6. Kim DH (1999) Soybean Science. Dae-Kwang Publishing, Seoul, Korea, p 102

7. Kim JY, Kim JH, Kim JK, Moon KD (2000) Quality attributes of whole soybean flour tofu affected by coagulant and theirs concentration. Korean J Food Sci Technol, 32, 402-409

8. Lee BY, Kim DM, Kim KH (1990) Studies on the processing aptitude of the Korean soybean cultivars for soybean curd. Korean J Food Sci Technol, 22, 363-368

9. Myung JE, Hwang IK (2008) Functional components and antioxidative activities of soybean extracts. Korea Soybean Digest, 25, 23-29

10. Kim YH (1999) Chemical composition and hardness of black-colored soybean seed. Soonchunhyang J Nat Sci, 5, 301-306

11. Kim KS, Kim MJ, Lee KA, Kwon DY (2003) Physico-chemical properties of Korean traditional soybeans.
Korean J Food Sci Technol, 35, 335-341

12. Kim SH, Kwon TW, Lee YS, Choung MG, Moon GS (2005) A major antioxidative components and comparison of antioxidative activities in black soybean. J Korean Food Sci Technol, 37, 73-77

13. Lee HJ, Hwang IK (1994) Textural characteristics and microstructure of soybean curds prepared with different coagulants. Korean J Soc Food Sci, 10, 284-290

14. Kang HY (1997) Tofu taste and quality as affected by coagulants. Korea Soybean Digest, 14, 37-42

15. Kim GW, Kim GH, Kim JS, An HY, Hu GW, Son JK, Kim OS, Cho SY (2008) Quality of tofu prepared with deep seawater as coagulant. Korean J Fish Aquat Sci, 41, 77-83

16. Jung GT, Ju IO, Choi JS, Hong JS (2000) Preparation and shelf-life of soybean curd coagulated by fruit juice of Schizandra chinensis RUPRECHT (Omija) and Prunus mume (maesil). Korean J Food Sci Technol, 32, 1087-1092

17. Lee MY, Kim SD (2004) Shelf-life and quality characteristics of tofu coagulated by calcium lactate. J Korean Soc Food Sci Nutr, 33, 412-419

18. Shin YM, Kwon OY, Lee KJ, Kim HY, Kim MR (2005) Storage characteristics of tofu added with spinach juice. Chungnam J Human Ecology, 18, 75-82

19. Kim JY, Park GS (2006) Quality characteristics and shelf-life tofu coagulated by fruit juice of pomegranate. Korean J Food Culture, 21, 644-652

20. Lee JS, Lee SW (1990) Effect of water extracts in Omija (Schizndra chinenesis Baillon) on alcohol metabolism. J Korean Soc Food Cult, 5, 259-263

21. Ko SH, Choi SW, Ye SK, Yoo SH, Kim HS, Chung MH (2008) Comparison of anti-oxidant activities of seventy herbs that have been used in Korean traditional medicine. Nutr Res Pract, 2, 143-151

22. Kwon HJ, Park CS (2008) Biological activities of extracts from Omija (Schizandra chinensis Baillon). Korean J Food Preserv, 15, 587-592

23. Choi EO, Lee BS, Park YS, Seo EO, Chung BW (2008) Extraction condition from Schizandra chinensis Baillon for beverage development of high Scizandrin concentration. Korean J Biotechnol Bioeng, 23, 271-275

24. Kim DG, Kim MB, Kim H, Park JH, Im JP, Hong SH (2005) Herb medicinal pharmacognosy. Shinill Books, Seoul, Korea, p 407

25. AOAC (2002) Official Methods of Analysis 16th ed. The Association of Official Analytical Chemists, Washington 
DC, USA, p 8-20

26. Seo YJ, Kim MK, Lee S, Hwang IK (2010) Physicochemical characteristics of soybeans cultivated in different regions and the accompanying soybean curd properties. Korean J Food Cookery Sci, 26, 441-449

27. Park CK, Hwang IK (1994) Effect of coagulant concentration and phytic acid addition on the contents of $\mathrm{Ca}$ and $\mathrm{P}$ and rheological property of soybean curd. Korean J Food Sci Technol, 26, 355-358

28. Jeon MK, Kim MR (2006) Quality characteristics of tofu prepared with herbs. Korean J Soc Food Cookery Sci, 22, 30-36

29. Park BH, Cho HS, Jeon ER. Kim SD, Koh KM (2009) Quality characteristics of soybean curd prepared with lotus leaf powder. J Korean Soc Food Cult, 24, 315-320
30. Kim KS (2007) Functional ingredient compositions of soybean curds (Tofu) made with black soybeans (Huktae) and white soybeans (Baktae). Korean J Food Nutr, 20, 158-163

31. Ko KH, Moon SH, Yoo YJ, Kim IC (2013) Characteristics of soybean curds manufactured by various bitterns. Korean J Food Preserv, 20, 37-44

32. Shin MK, Kim MH, Hong GJ (2013) Physiochemical characteristics and antioxidant activity of soybean curd added with saltwort (Salicornia herbacea L.). Korean J Food Cookery Sci, 29, 123-127

33. Kim JS, Choi SY (2008) Quality characteristics of soybean curd with Omija extract. Korean J Food Nutr, $21,43-50$ 